\title{
EFFECT OF VARIATION OF OPERATIONAL REGIMES IN BUILDING ENVIRONMENT ON RESULTS OF ITS ENERGY AND EXERGY ASSESSMENTS
}

\author{
Volodymyr VOLOSHCHUK ${ }^{1}$ \\ National Technical University of Ukraine "Igor Sikorsky Kyiv Polytechnic Institute", \\ Kyiv, Ukraine
}

\begin{abstract}
For further development of the dynamic exergy analysis within built environment the work proposes to take into account stochastic nature of variations of operational regimes. Using the probability theory and statistics methods, the set of parameters considered as relevant for uncertainty conditions are presented. It is shown that characteristics of buildings (insulation, window performance, heat recovery, etc.) and type of the heating system have undoubtedly a strong influence not only on the energy/exergy demand and consumption but also on the sensitivity of the energy/exergy parameters to variations of external conditions. According to the results obtained after implementations of energy efficient solutions coefficient of variation of energy/exergybased parameters can be increased up to two times.
\end{abstract}

Keywords: exergy-based methods; building environment; stochastic variations; reference environment

\section{INTRODUCTION}

Operating regimes of thermal systems providing thermal comfort in buildings vary and are usually very close to the reference conditions and therefore their exergy performance is largely influenced by the choice of the reference

1 Corresponding author: National Technical University of Ukraine "Igor Sikorsky Kyiv Polytechnic Institute", Faculty of heat power engineering, Department of Nuclear Power Stations and Engineering Thermal Physics, Politehnichna st. 56, 03056 Kyiv, Ukraine, e-mail: Vl.Volodya@gmail.com, tel.+380442048098 
environment. Besides a distinguish feature of the built environment is that the reference conditions change randomly and the tempo are different over different time periods under consideration.

Two approaches are proposed nowadays to perform exergy analysis within built environment - steady state and dynamic.

Steady state calculations may lead to big uncertainties when it comes to the estimation of the exergy flows while dynamic ones are more accurate and a deeper insight into the system behavior can be expected. On the other hand dynamic exergy analyses would naturally be more time consuming than stationary ones. A simplified steady-state analysis has proven to be adequate for the first estimations on the performance of different building systems. An evaluation of the error of steady-state exergy assessment as compared to dynamic approaches is mandatory.

First studies on the difference between steady state and dynamic exergy analysis of energy systems in the built environment have been conducted by Angelotti and Caputo [1]. They evaluate the difference between steady state and dynamic analysis for heating and cooling systems in two representative Italian climates. Steady state exergy analysis is performed using design outdoor temperature and mean monthly outdoor temperatures for the coldest (January) and warmest (July) months. Dynamic efficiencies are estimated by averaging instantaneous exergy values calculated on an hourly basis from dynamic analysis over a month. The latter analysis is also regarded as quasi-steady state approach [2]. According to $[1,2]$ steady state exergy efficiencies of the chosen building systems for the heating cases based on average outdoor temperatures but not on design conditions are very close to those resulting from dynamic exergy analysis. In turn, for cooling purposes, in case of using steady state approach, it is possible to use only design values for the estimation of the exergy efficiency which leads to great mismatching as compared to quasi-steady state analysis differences of up to $40 \%$ are found. Later the same authors $[3,4]$ confirm once more that dynamic approach is preferable when cooling cases or the warmer the climates are considered.

Sakulpipatsin et al. [5] evaluate inaccuracies when determining the exergy of air in buildings for different statistic values of the variables defining the reference environment. They show that the use of steady state approach causes a severe underestimation of the exergy content as compared with dynamic one. In the hot and humid climate (Bangkok, Thailand) the exergy calculation results of dry air are $93 \%$ (for warm season of a year) and $89 \%$ (for cold season of a year) less than the exergy results of the dynamic simulation. In cold climate (De Bilt, Netherlands) the exergy contents of dry air calculated with stationary method are $5.8 \%$ (for warm season) and $14.5 \%$ (for cold season) less the exergy contents of the dynamic calculation. For temperature sea climate zone (Lisbon, 
Portugal) the underestimations are $82.8 \%$ and $23.4 \%$ for warm and cold seasons respectively.

Jansen [6] focuses on the calculation of the exergy demand for heating and the comparison of the results from a dynamic ( 0.5 -hourly based) simulation versus a steady state (monthly based) calculation. The results obtained show that in the Dutch climate the dynamically calculated exergy demands of the cases studied are largely between $14-17 \%$ higher than the steady state ones. In other climates the following deviations were obtained: Sweden (Stockholm) 11\%, Germany (Berlin) 15\%, Spain (Madrid) 34\%.

Torio [7] proposes to use quasi-steady as an alternative hybrid assessment between fully dynamic and fully steady-state calculation methods. The exergy flows are evaluated following a steady-state approach, i.e. storage phenomena are disregarded, over discrete and short time-steps. A quasi-steady state approach allows accurate results for exergy analysis of building systems on a system level. Storage phenomena are regarded dynamically in terms of energy but are not regarded separately in detail in exergy terms. Only for storage systems dynamic equations have been derived and applied in [7].

Today exergy-based methods include conventional and advanced exergetic, exergoeconomic, and exergoenvironmental analyses and evaluations.

An exergoeconomic analysis is a unique combination of exergy analysis and cost analysis to provide the designer or operator of a thermal system with information crucial to the design of a cost-effective system. Exergoeconomics is based on the exergy costing principle, which rests on the notion that exergy is the only rational basis for assigning monetary values to energy streams and to the thermodynamic inefficiencies within the system [8]. One of the important aspects of exergoeconomics is the application of exergy for allocating costs to the products of a thermal system.

The paper makes an attempt to provide a theoretical framework for evaluation of energy/exergy parameters in varying operational regimes of built environment caused by fluctuating in outdoor environment (reference environment). The work also examines the deviations between dynamic and steady state approach when estimating energy/exergy parameters in conditions of Ukrainian climate. A parameter which would evaluate variability of energy/exergy-based values is proposed and estimated in the paper too.

\section{METHODOLOGY}

The study focuses on the case of space heating. It is proposed to consider meteorological parameters influencing the thermal regimes of a building as statistical data type which can be inferred under the framework of probability theory. It should be noted that variations of these parameters result in changes of 
energy characteristics of buildings not only within a chosen period in a year (month, heating season, etc.) but also from year to year.

Accepting the choice of system boundaries according to [2] and neglecting energy stored in the inside air, an energy balance in a building over quite small time-step $\tau_{k}$ can be written as follows.

$$
\begin{gathered}
Q_{\text {trans }}\left(\tau_{k}\right)+Q_{\text {inf }}\left(\tau_{k}\right)+Q_{\text {vent }}\left(\tau_{k}\right)+ \\
+Q_{\text {int }}\left(\tau_{k}\right)+Q_{\text {sol }}\left(\tau_{k}\right)+Q_{\text {dem }}\left(\tau_{k}\right)=0,
\end{gathered}
$$

where $Q_{\text {trans }}\left(\tau_{k}\right)$ are the energy flows through external surfaces of a building due to transmission,

$Q_{\text {inf }}\left(\tau_{k}\right), Q_{\text {vent }}\left(\tau_{k}\right)$ are energy flows due to infiltration and ventilation respectively,

$Q_{\text {int }}\left(\tau_{k}\right)$ are energy gains from internal heat loads,

$Q_{\text {sol }}\left(\tau_{k}\right)$ are energy gains from the sun,

$Q_{\text {dem }}\left(\tau_{k}\right)$ are energy demands for space heating.

If energy flows related to transmission, ventilation and infiltration constitute the largest part of all energy flows (this can be accepted for buildings with poor thermal characteristics which is typical for Ukraine) heat demands can be regarded as $\Delta T$-dependent flows and estimated as

$$
Q_{\text {dem }}\left(\tau_{k}\right)=k \cdot \Delta T\left(\tau_{k}\right),
$$

where $k$ is a proportionality constant,

$\Delta T\left(\tau_{k}\right)$ is within time-step $\tau_{k}$ temperature difference between inside and outside air which vary due to fluctuation of outside temperature (inside temperature is set to be constant).

There are two approaches to estimate exergy demand for space heating: simplified and detailed [2]. In the given investigations a simplified method will be applied according to which the exergy demand is evaluated assuming the energy for heating to be delivered at indoor temperature $\left(T_{i n}\right)$

$$
E_{d e m}\left(\tau_{k}\right)=Q_{d e m}\left(\tau_{k}\right) \cdot\left(1-\frac{T_{0}\left(\tau_{k}\right)}{T_{i n}}\right),
$$


where $E_{\text {dem }}\left(\tau_{k}\right)$ and $Q_{\text {dem }}\left(\tau_{k}\right)$ stand for the exergy demand and the energy demand for heating respectively within the given time-step $\tau_{k}$, $T_{0}\left(\tau_{k}\right)$ is reference (outdoor) temperature specified for the given time-step $\tau_{k}$, $T_{\text {in }}$ is indoor air temperature which is set to be constant.

Taking into account assumption (2.2) equation (2.3) can be written as non-linear (quadratic) function of the temperature difference $\Delta T\left(\tau_{k}\right)$

$$
E_{\text {dem }}\left(\tau_{k}\right)=k \cdot \Delta T\left(\tau_{k}\right) \cdot\left(1-\frac{T_{0}\left(\tau_{k}\right)}{T_{i n}}\right)=\frac{k}{T_{i n}} \cdot\left(\Delta T\left(\tau_{k}\right)\right)^{2},
$$

Consider a heating system enclosing a generating unit and an emission system. The objective is to determine the cost at which heat as a product of the given thermal system is generated. In accord with the principles of exergoeconomics [8] the cost balance applied to the heating system can be written as

$$
C_{P}\left(\tau_{k}\right)=C_{F}\left(\tau_{k}\right)+Z\left(\tau_{k}\right),
$$

or

$$
c_{P} \cdot E_{P}\left(\tau_{k}\right)=c_{F} \cdot E_{F}\left(\tau_{k}\right)+Z\left(\tau_{k}\right),
$$

where $E_{P}\left(\tau_{k}\right)$ and $E_{F}\left(\tau_{k}\right)$ are the exergy rates associated with product and fuel respectively,

$C_{P}\left(\tau_{k}\right)$ and $C_{F}\left(\tau_{k}\right)$ are the corresponding cost rates, and $c_{P}$ and $c_{F}$ are the costs per unit of exergy for product and fuel,

$Z\left(\tau_{k}\right)$ is the sum of cost rates associated with capital investment and operating maintenance expenditures (excluding fuel costs).

The exergy of product $E_{P}\left(\tau_{k}\right)$ can be calculated using the following assumption [2]. The air temperature of the room, $T_{i n}$, is assumed to be homogeneous and constant. The surface temperature of the heater, $T_{\text {heater }}$, is estimated as the temperature difference, $\Delta T_{\text {heater }}$, between the surface of emission system and the room air

$$
T_{\text {heater }}=T_{\text {in }}+\Delta T_{\text {heater }} \text {, }
$$


where the temperature difference $\Delta T_{\text {heater }}$ is set to be constant as a first approximation

Then exergy rate associated with the product is defined by

$$
E_{P}\left(\tau_{k}\right)=Q_{\text {dem }}\left(\tau_{k}\right) \cdot\left(1-\frac{T_{0}\left(\tau_{k}\right)}{T_{\text {heater }}}\right) .
$$

In case of $\Delta T$-dependent assumption for energy flows the exergy of product is also expressed as non-linear function of the temperature difference $\Delta T\left(\tau_{k}\right)$

$$
E_{P}\left(\tau_{k}\right)=\frac{k}{T_{\text {in }}+\Delta T_{\text {heater }}} \cdot\left[\Delta T_{\text {heater }} \cdot \Delta T\left(\tau_{k}\right)+\left(\Delta T\left(\tau_{k}\right)\right)^{2}\right] .
$$

Assuming that combustion air enters and flue gases leave the boiler with negligible exergy and cost, exergy rate associated with the fuel in terms of exergoeconomics is equal the the exergy of fuel $E_{F}\left(\tau_{k}\right)$ which is burnt in the generation unit (natural gas, oil, etc.) and can be evaluated as

$$
E_{F}\left(\tau_{k}\right)=\frac{Q_{d e m}\left(\tau_{k}\right)}{\eta},
$$

where $\eta$ is energetic efficiency of the heating system.

The total energy/exergy variable for an entire period of time (month, heating season, etc) evaluated by means of dynamic method is calculated as

$$
Y_{t o t}^{d y n}=\sum_{k=1}^{N} Y\left(\tau_{k}\right)
$$

where $Y\left(\tau_{k}\right)$ specified variable for every time-step $\tau_{k}$.

In case of steady-state approach the total energy/exergy variable is calculated using straight average values of meteorological parameters influencing processes of thermal regimes in built environment.

When estimating annualized cost per unit of heating exergy the following formula can be applied

$$
c_{P}=c_{F} \cdot \frac{\frac{Q_{\text {dem }, \text { tot }}}{\eta}+Z_{\text {tot }}}{E_{P, t o t}},
$$


where $Q_{\text {dem,tot }}, Z_{\text {tot }} E_{P, t o t}$ are total annual values calculated with dynamic or stationary approach.

Assume that temperature difference $\Delta T$ is the main parameters which influences energy/exergy parameter $Y$ within built environment $(\Delta T$ dependent case).

If to accept that temperature difference $\Delta T$ is random variable with an appropriate probability density function $f(\Delta T)$ then the total energy/exergy parameter $Y_{t o t}^{d y n}$ for a specified period based on dynamic approach can be calculated as

$$
Y_{\text {tot }}^{d y n}=\int_{\Delta T_{\min }}^{\Delta T_{\max }} Y(\Delta T) \cdot f(\Delta T) d \Delta T,
$$

where $\Delta T_{\min }, \Delta T_{\max }$ - minimum and maximum value of $\Delta T$ within its distribution.

In case of steady-state method

$$
Y_{\text {tot }}^{\text {steady }}=Y\left[\int_{\Delta T_{\text {min }}}^{\Delta T_{\text {max }}} \Delta T \cdot f(\Delta T) d \Delta T\right]=Y\left(\Delta T_{\text {mean }}\right),
$$

where $\Delta T_{\text {mean }}$ is the straight average temperature difference.

If a variable $Y$ is a linear function of $\Delta T$ then the energy/exergy variable based on dynamic method $Y_{t o t}^{d y n}$ is equal to one based on steady-state method $Y_{\text {tot }}^{\text {steady }}$ and (2.13) can be written as

$$
\begin{gathered}
Y_{\text {tot }}^{d y n}=\int_{\Delta T_{\text {min }}}^{\Delta T_{\text {max }}} k \cdot \Delta T \cdot f(\Delta T) d \Delta T=k \cdot \int_{\Delta T_{\text {min }}}^{\Delta T_{\text {max }}} \Delta T \cdot f(\Delta T) d \Delta T= \\
=k \cdot \Delta T_{\text {mean }}=Y_{\text {tot }}^{\text {steady }}=Y\left(\Delta T_{\text {mean }}\right),
\end{gathered}
$$

where $k$ is a proportionality constant.

In case of non-linear relationship between $Y$ and $\Delta T$ the dynamic variable $Y_{t o t}^{d y n}$ is not equal to the steady-state one $Y_{\text {tot }}^{\text {steady }}$.

The deviation between the dynamic and steady state approaches when calculating energy/exergy-based values are defined as 


$$
\chi=\frac{Y^{d y n}-Y^{s t e a d y}}{Y^{d y n}} \cdot 100 \%,
$$

where $Y^{d y n}$ and $Y^{\text {steady }}$ are values based on dynamic and steady-state approach respectively.

To measure the relative variability of energy/exergy-based values in building environment due to random fluctuations of outdoor parameters it is proposed to use coefficient of variation as a statistical measure of the dispersion in a data series around the mean

$$
C V=\frac{\sigma_{Y}}{Y_{\text {mean }}}
$$

where $\sigma_{Y}$ and $Y_{\text {mean }}$ are standard deviation and mean of an energy/exergy-based value $Y$.

The analysis is performed for a typical Ukrainian house. The dwelling has two floors with a gross floor area of $150 \mathrm{~m}^{2}$ and a volume of $350 \mathrm{~m}^{3}$. For the reference case weighted average insulation value of non-glazed external surfaces is $0.67 \mathrm{~W} /\left(\mathrm{m}^{2} \cdot \mathrm{K}\right)$. U-value of windows including frames is $1.67 \mathrm{~W} /\left(\mathrm{m}^{2} \cdot \mathrm{K}\right)$. Infiltration rate is regarded as $1 \mathrm{~h}^{-1}$. Internal heat gains are defined with a constant value of $10 \mathrm{~W} / \mathrm{m}^{2}$. Setpoint for the indoor temperature is $18{ }^{\circ} \mathrm{C}$. The fraction of east and west oriented glazing is $30 \%$, of the south one $-50 \%$, of the north one $-20 \%$. A mechanical ventilation without heat recovery is installed in the dwelling. The cost of fuel for heating is 0.1 Euro/kW-hr.

\section{RESULTS}

Distribution of daily temperature differences and daily heat demand vs. temperature differences relationships over a year for the reference case is shown in the Figure 1. The histogram of statistical data of daily temperature differences is represented with normal and Pearson Type I distribution (see Fig. 1,a). Heat demand as a function of daily temperature differences can be represented as a linear regression (see Fig. 1,b).

Deviations between dynamic and steady state approach estimated with the help of accepted theoretical framework for the chosen year with data shown in the Figure 1 are presented in Table 1.

Annual statistical values of heating demands, exergy demands and average cost per unit of exergy for heating estimated over 27-year period with the help of steady-state and dynamic methods for the reference dwelling are introduced in the Figure 2, a, b, c respectively. 


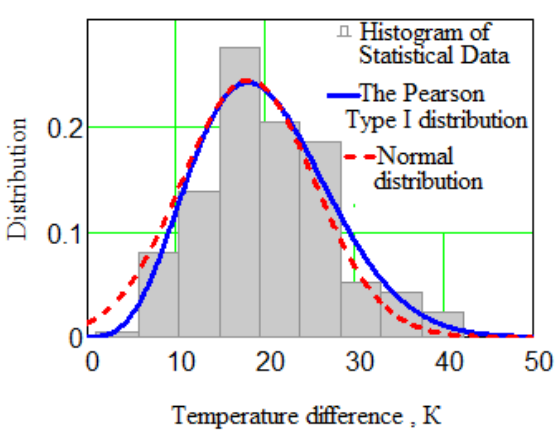

a)

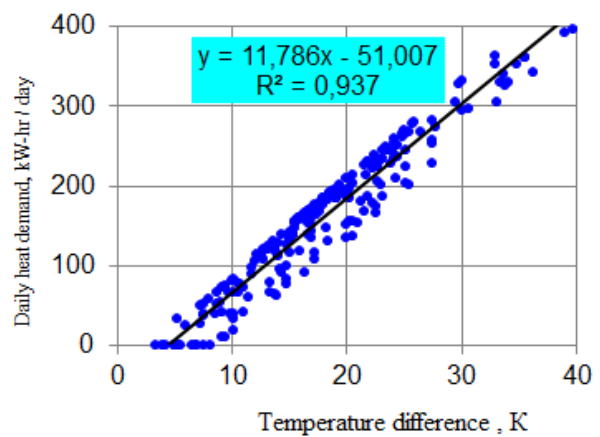

b)

Fig. 1. Distribution of daily temperature differences and daily heat demands vs. temperature differences relationships over a year for the reference case

Table 1. Deviations between dynamic and steady state approach estimated with the help of accepted theoretical framework

\begin{tabular}{|l|c|c|}
\hline \multirow{2}{*}{$\begin{array}{l}\text { Type of distribution of } \\
\text { daily temperature }\end{array}$} & \multicolumn{2}{|c|}{ Deviations, \% } \\
\cline { 2 - 3 } differences & Annual heat demand & Annual exergy demand \\
\hline Normal & 0.0 & 14.4 \\
\hline Pearson Type I & 0.0 & 12.2 \\
\hline
\end{tabular}

Data about deviations between dynamic and steady state energy/exergy parameter for each year over 27-year period are presented in the Figure 3.

Figure 4 illustrates changes of deviations between dynamic and steady state approach for annual energy/exergy parameters and of appropriate coefficients of variation when improving thermal performance of built environment according to Table 2 .

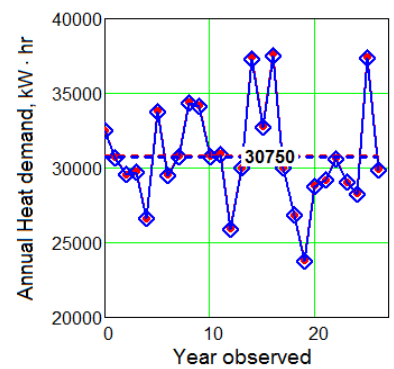

a)

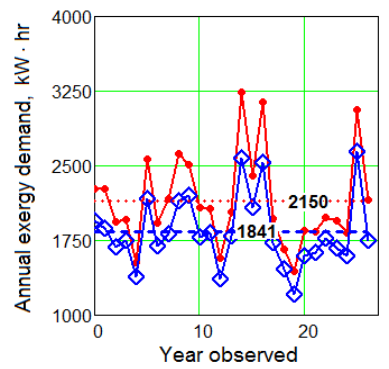

b)

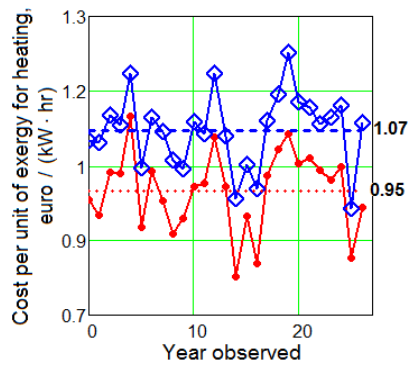

c)

$\Leftrightarrow$ Parameter based on steady-state method --- Parameter based on steady-state method and averaged over 27-year period

$\ldots$ Parameter based on dynamic method …. Parameter based on dynamic method and averaged over 27-year period

Fig. 2. Annual statistical values of analyzed energy/exergy parameters estimated with the help of steady-state and dynamic methods for the reference dwelling 


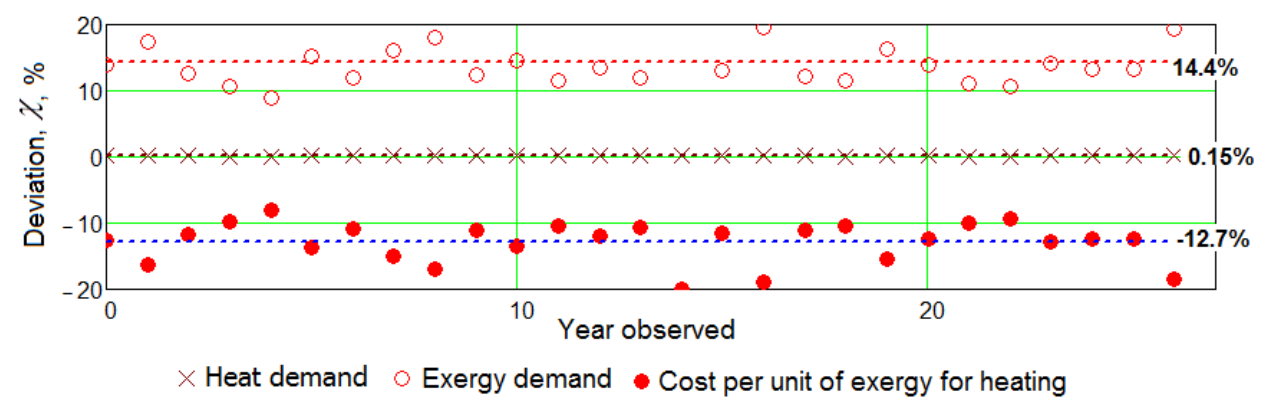

Fig. 3. Data about deviations between dynamic and steady state approach over 27-year period

Table 2. Change of building characteristics for investigation of deviations and coefficients of variation

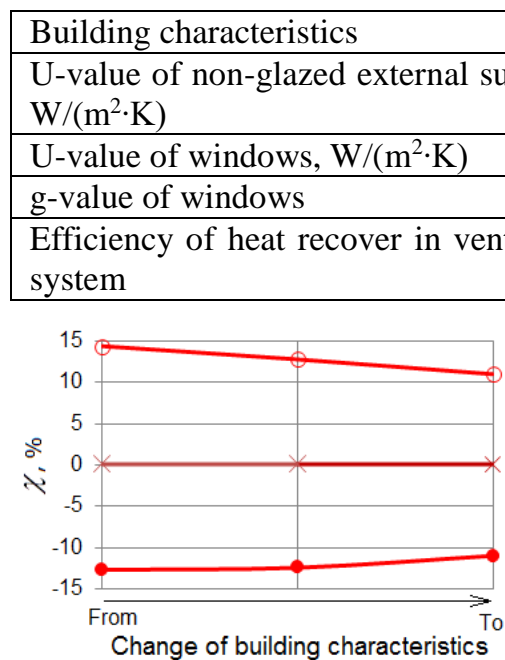

a)

\begin{tabular}{|l|l|l|}
\hline From & To \\
\hline 0.67 & 0.25 \\
\hline 1.67 & 1.0 \\
\hline 0.6 & 0.7 \\
\hline & 0 & 0.8 \\
\hline
\end{tabular}

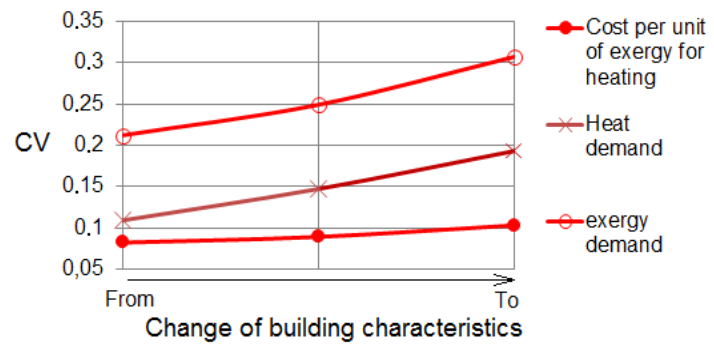

b)

Fig. 4. Values of deviation betweeen dynamic and steady state approach for annual energy/exergy parameters and of coefficient of variation with different building characteristics

\section{DISCUSSION}

27-year period of daily weather data for the city of Rivne located in the western part of Ukraine were used for the analyses. So, 24-hour time step $\tau_{k}$ was assumed for dynamic energy calculations. It doesn't really satisfy all the 
requirements of such type of simulation but is considered as a first approximation.

According to results obtained energy/exergy variations of built environment parameters being functions of weather conditions can be regarded as random and can be treated using probability theory. For example, one of the main influence parameter - temperature difference between indoor and outdoor air within a heating season can be evaluated with Pearson Type I or even normal distribution (see Fig. 1,a). It can be seen from Fig. 1,b that heat demand in buildings with low thermal properties can be represented as a linear function of temperature differences between indoor and outdoor having the same probability distribution as its argument.

As a result there is a possibility to estimate different methods of evaluation of energy/exergy parameters using probability theory.

For example, deviation between dynamically and steady-state calculated heat demand estimated with the help of methods of probability theory using formula (2.13), (2.14) and (2.16) is zero. This is completely confirmed theoretically when accepting linear relationship between energy/exergy variable parameter and temperature difference $\Delta T$ (see formula (2.15)). Statistical treatment of data has also shown that energy demand for space heating can be calculated using annual steady-state approach (see Fig. 2,a; 3; 4,a) which is widely used in practice.

On the contrary, we can observe a quite substantial mismatch between exergy demand resulting from a dynamic method and that resulting from an annual steady state method. The table 1 shows that assuming normal distribution of the daily temperature difference between indoor and outdoor as a random variable the dynamic exergy demand is annually $14.4 \%$ higher the steady state (yearly based) exergy demand. In case of Pearson Type I distribution of the daily temperature difference the dynamic exergy demand is annually $12.2 \%$ higher the steady state (yearly based) exergy demand. Such mismatching is reasoned with the fact that relationship between daily exergy demand and temperature difference is quadratic (non-linear). This is confirmed with statistical treatment of data (see Fig. 2,b; 3; 4,a) where the analyzed deviation for the building reference reaches $14.4 \%$ which completely agrees with the theoretical framework.

Although some approximations were introduced within the investigations the results obtained are in good agreement with others' $[5,6]$.

For evaluation of mismatching between annualized costs per unit of exergy associated with product of space heating system "heat-generation unit-emission system" resulting from dynamic vs. stationary methods the following peculiarities should be taken into account. In formula (2.12) heat demands calculated on the base of dynamic vs. steady-state approach are equal 
$\left(Q_{d e m, t o t}^{d y n}=Q_{d e m, t o t}^{\text {stedy }}\right)$ which is proved above. Assuming that annual capital investment charges and operating and maintenance expenses are constant, energy efficiency doesn't change it can be concluded that annualized costs per unit of heating exergy $c_{P}$ (and an appropriate deviation) resulting from the dynamic vs. stationary methods differ due to different values of exergy of product $E_{P, t o t}^{d y n}$ and $E_{P, t o t}^{\text {steady }}$ respectively. Using this assumption it can be concluded that unit costs $c_{P}$ based on steady state approach are overestimated as compared to dynamic method. In the analyzed cases this overestimation varies between 11-13\% (see Fig. 3, 4).

The proposed parameter for evaluation of variations of energy/exergy variables due to fluctuating outdoor environment should also be taken into account. For the reference case of building the coefficient of variation of annual exergy demands is 0.21 , of annual energy demands is 0.11 and of annualized costs per unit of exergy for heating is 0.08 . When improving thermal performance of building variability of analyzed energy/exergy parameters is increased up to two times (see Fig. 4). If to analyze the formula (2.12) it can be concluded that variation of annualized unit costs $c_{P}$ also depends on the share of capital investment and operating maintenance expenditures $Z_{t o t}$. The higher $Z_{t o t}$ the higher is the coefficient of variation of $c_{P}$.

\section{CONCLUSIONS}

Fluctuating in outdoor environment (reference environment) causes variation of operational regimes in building systems which should be taken into account when applying exergy-based methods. Which type of assessment should be used - steady state or dynamic is mandatory.

In the work a theoretical framework based on probability theory and statistics was proposed to compare steady-state vs. dynamic approaches applied in energy/exergy analysis within built environment. Tor $\Delta T$-dependent cases it was shown that in case of linear relationships between energy/exergy variable and its argument changing in a random manner stationary method can be applied. This is proved using the theoretical framework and confirmed with statistical treatment of data when estimating energy demand for space heating. On the contrary, when energy/exergy variable is a non-linear function of stochastically changing meteorological parameters dynamic approach is required. In the Ukrainian climate the dynamically calculated annual exergy demands of the cases studied are largely between 10-15\% higher than the steady state results. The lower value of the deviation is for building with improved 
thermal performance. Estimation of costs per unit of exergy as a product of a heating system being a non-linear function of outdoor environment also shows that dynamical method should be applied. Based on the proposed theoretical approach and statistical treatment of data it was shown that annualized costs per unit of exergy associated with product of space heating system for analyzed cases of built environment are annually 11-13\% lower the steady state (yearly based) ones. Mismatching is decreased when thermal performance of building is increased.

To measure the relative variability of energy/exergy-based parameters it is proposed to use coefficient of variation as a statistical measure of the dispersion around mean values. It was shown that for the reference case of the building the coefficients of variation are $0.08,0.11$ and 0.21 for cost per unit of heating exergy, heating demand and exergy demand respectively. Improving thermal performance of building increases the coefficients of variation of energy/exergy parameters analyzed.

The results obtained show that further investigations are necessary to evaluate variations of meteorological parameters and their influence on energy/exergybased methods including advanced exergy evaluation, thermoeconomics, and exergoenvironmental analysis.

\section{ACKNOWLEDGEMENTS}

This work was supported as part of a Thematic Partnership ReNERGY "Shared visions of sustainable energy systems in cities of the Baltic Sea Region" financed within Baltic Sea Region Programme.

\section{REFERENCES}

1. Angelotti A., Caputo P.: The exergy approach for the evaluation of heating and cooling technologies; first results comparing steady state and dynamic simulations, in 2nd PALENC Conference and 28th AIVC Conference on Building Low Energy Cooling and Advanced Ventilation Technologies in the 21st Century (2007) Crete, Greece.

2. IEA ECBCS Annex 49 Final Report - Low Exergy Systems for HighPerformance Buildings and Communities - Detailed Exergy Assessment Guidebook for the Built Environment, edit. H. Torio and D. Schmidt, Fraunhofer IBP, Germany 2011.

3. Angelotti A., Caputo P.: Dynamic exergy analysis of an air source heat pump, in International Conference on Exergy and Life Cycle Analysis. Nysiros (ELCAS) (2009) Nisyros, Greece. 
4. Angelotti A., Caputo C., Solaini G.: Steady versus dynamic exergy analysis: the case of an air source heat pump, Int. J. Exergy, 11, 4 (2012) 460-472.

5. Sakulpipatsin P., van der Kooi H. J., Itard L. C. M., Boelman E. C.: The Influence of Possible Definitions of a Reference Environment to Determine the Exergy of Air in Buildings, Int. J. Exergy, 5, 3 (2008), 275-295.

6. Jansen S.C., Luscuere P.G., Linden A.C. v.d.: Exergy Demand of Heating in Buildings - Steady State Versus Dynamic Approach, in 2nd International Exergy, Life Cycle Assessment and Sustainability Workshop \& Symposium (ELCAS-2) (2011) Nisyros, Greece.

7. Torío H.: Comparison and optimization of building energy supply systems through exergy analysis and its perspectives, Doctoral thesis, Technische Universitat Munchen 2012.

8. Bejan A., Tsatsaronis G., Moran M.: Thermal Design and Optimization, New York, Wiley 1996.

\section{WPŁYW ZMIENNOŚCI FUNKCJONOWANIA UKŁADÓW OGRZEWANIA BUDYNKÓW NA WYNIKI ANALIZY EGZERGETYCZNEJ I ENERGETYCZNEJ}

\section{Streszczenie}

Jedną z podstawowych cech układów ogrzewania budynków jest ich zmienność działania. Przemiany $\mathrm{w}$ procesie ogrzewania budynku uwarunkowane są głównie czynnikami klimatyczno-pogodowymi (temperatura, promieniowanie słoneczne, prędkość wiatru, ciśnienie, wilgotność, itp), i są o charakterze losowym. Egzergetyczne cechy takich systemów w dużej mierze zależą od zmian parametrów środowiskowych. W celu dalszego rozwoju dynamicznej analizy egzergetycznej systemów ogrzewania budynków w pracy naukowej uwzględniony został stochastyczny charakter zmienności ich działania. Biorąc pod uwagę teorię prawdopodobieństwa i metody statystyki matematycznej, zostały zaproponowane kryteria, które uwzględniają te zmienności.

W przypadku zależności nieliniowej pomiędzy argumentami i funkcjami, co jest charakterystycznym dla wskaźników egzergetycznych, uśrednienie wartości funkcji, a nie funkcji średnich wartości argumentów powinno być wykorzystywane do analizy. Uwarunkowano, że charakterystyka budynków (typ konstrukcji, system odzyskiwania energii, itp.) i typ systemu grzewczego wpływają nie tylko na potrzeby energii i egzergii, ale również na ich wrażliwość na zmiany warunków zewnętrznych. $Z$ badania wynika, że po wdrożeniu rozwiązań energooszczędnych zmienność parametrów egzergetycznych oraz energetycznych może być zwiększona dwukrotnie. W pracy zaprezentowano wyniki stosowania dynamicznej analizy do oceny egzergonomicznej

Słowa kluczowe: metody analizy egzergetycznej; budynek; zmienna stochastyczna; środowisko

Editor received the manuscript: 14.12 .2016 